\title{
Unjuk Kerja dan Pemeliharaan Gear Pump pada Unit Excavator 220 LC
}

\author{
Veny Selviyanty.YH \\ Jurusan Teknik Mesin Sekolah Tinggi Teknologi Pekanbaru \\ e-mail: venyselviyanty@gmail.com
}

\begin{abstract}
Abstrak
Gear pump (pompa roda gigi) adalah jenis pompa positive displacement dimana fluida akan mengalir melalui celah-celah roda gigi dengan dinding rumahnya disebut sebagai pompa karena fluida yang dialirkan pada umumnya berupa cairan (liquid) atau bubur (slurry). Sedangkan pompa positive displacement berarti pompa tersebut menghisap sejumlah fluida yang terjebak yang kemudian ditekan dan dipindahkan ke arah keluaran (outlet). Gear pump sering digunakan untuk aplikasi hydrolic fluid power. Dalam pengoperasiannya sebuah komponen gear pump excavator dapat mengalami kegagalan, meskipun komponen tersebut masih dalam keadaan bagus/ baru. Untuk menganalisa penyebab terjadi kegagalan gear pump ini dilakukan pengujian yang meliputi pengujian yang bersifat merusak (destructive material testing) menggunakan uji kekerasan dan pengujian yang tidak merusak (nondestructive material testing) menggunakan uji fraktografi, metallografi dan pengujian komposisi kimia. Dari hasil pemeriksaan di labor menunjukan bahwa Gear Pump Excavator mengalami kerusakan pada gigi penggerak di bagian luar dan gigi bagian dalam, photo makro roda gigi bagian luar dalam penampang melintang menunjukan adanya cacat Deformasi / Perubahan Bentuk akibat beban bentur pada permukaan roda gigi. Roda gigi yang menerima beban putar/ gesek mengalami aus sesuai dengan arah putaran geardan pada permukaan patahan dan menunjukkan terdapatnya inklusi yang terkonsentrasi mengarah ke permukaan material gear pump excavator sehingga menyebabkan terjadinya aus. Pada material gear pump excavator yang mengalami kegagalan bila dilihat dari bentuk patahannya termasuk kepada jenis beban fatik karena sebelum patah gear pump excavator mengalami cacat deformasi.
\end{abstract}

Kata Kunci : Kegagalan gear pump excavator, pengujian merusak dan pengujian tidak merusak

\begin{abstract}
Gear pump is a positive displacement pump type where the fluid will flow through the gear cavities with the wall of the house is called a pump because the fluid that flows is generally liquid or slurry. While the positive displacement pump means the pump sucks a trapped amount of fluid which is then pressed and transferred to the outlet. Gear pump is often used for hydrolic fluid power applications. In operation a gear pump excavator component can fail, although the component is still in good condition / new. To analyze the cause of the failure of this gear pump, the test includes destructive material testing using hardness test and non-destructive material testing using fractography, metallography and chemical composition test. From the laboratory results showed that the Gear Pump Excavator was damaged in the outer gear and the inner teeth, the outside macro gear photo in the cross section shows the defect Deformation / Change of Shape due to the impact load on the gear surface. The gears accepting the rotational load are worn in the direction of the rotation of the gear and on the fracture surface and indicate the presence of concentrated inclusions leading to the surface of the excavator gear pump material causing wear. In the material gear pump excavator that fails when viewed from the fracture form including the type of fatigue load because before the broken gear pump excavator deformed defect.
\end{abstract}

Key Words : Failure of gear pump excavator, damage test and non destructive testing

SURYA TEKNIKA Vol. 5 No. 1, Juni $2017: 55-66$ 


\section{Pendahuluan}

Didalam sistem hidrolik terdapat yang disebut unit tenaga (Power unit) yang menyediakan energi hidrolik bagi kerja sistem. Dalam unit tenaga ini termasuk didalamnya tangki untuk menyimpan fluida dan sekaligus mendinginkannya, filter saat fluida meninggalkan tangki atau juga masuk kedalam tangki guna menjaga agar fluida tetap bersih. Motor penggerak yang biasa berupa motor listrik disambungkan dengan pompa hidrolik menggunakan kopling dan dipasang diatas tangki yang berfungsi sebagai landasan.

Kegagalan (failure) suatu komponen mesin hidrolik dapat didefinisikan sebagai ketidakmampuan komponen mesin hidrolik untuk melakukan fungsinya. Komponen mesin hidrolik yang membentuk sebuah mesin hidrolik atau peralatan sehingga jika satu komponen mesin hidrolik tersebut mengalami kegagalan, maka akan terjadi :

1. Mesin atau peralatan tersebut tidak dapat dioperasikan sama sekali.

2. Mesin atau peralatan dapat dioperasikan, tetapi tidak dapat berfungsi sebagaimana mestinya.

3. Mesin atau peralatan tidak aman bila dioperasikan.

Kegagalan (failure) ini harus dicari penyebabnya sehingga penyebab kegagalan tersebut bisa diatasi agar kerusakan yang sama tidak terulang lagi.

Penelitian ini membahas penyebab kegagalan/ aus pada gear pump excavator. Pengujian dan pemeriksaan dilakukan untuk memprediksi sisa umur pakai gear pump excavator yang telah mengalami proses keausan atau patahan pengujian meliputi : pengujian makrografi, metalografi, pemeriksaan komposisi kimia, kekerasan.

\section{Methodologi}

Prosedur penelitian yang digunakan dalam penelitian ini dapat dilihat pada diagram alir gambar 1. Penelitian ini dilaksanakan dengan pendekatan penelusuran kajian pustaka dan pengujian material Gear Pump Excavator di laboratorium. Pendekatan kajian pustaka diarahkan pada analisa terhadap teori - teori yang berhubungan dengan permasalahan yang dihadapi, kemudian dikaitkan dengan fakta kerusakan yang terjadi pada Gear Pump Excavator tersebut. Sedangkan uji laboratorium diarahkan untuk mempelajari fenomena fenomena yang terjadi pada material Gear Pump Excavator yang mengalami kerusakan/ aus.

Dengan pendekatan kajian pustaka dan pengujian laboratorium ini, maka dapat dilakukan pembahasan dan analisa untuk mendapatkan suatu kesimpulan penyebab terjadinya kerusakan dan fenomena kerusakan yang dialami oleh Gear Pump Excavator, serta upaya-upaya untuk mencegah terjadinya kerusakan yang sama.

Penelitian laboratorium dilakukan di Laboratorium BPPT dan Labotarium Metalurgi Fisik dan Manufaktur Pusat Penelitian Metalurgi Puspitek Serpong, terhadap material Gear Pump Excavator yang meliputi :

a) Pemeriksaan secara visual terhadap material Gear Pump Excavator.

b) Pengujian fraktografi.

c) Pemeriksaan metalografi.

d) Pengujian kekerasan.

e) Analisa komposisi kimia terhadap Gear Pump Excavator

f) Analisa penyebab kerusakan, meliputi : $\checkmark$ Analisa terhadap data dari kronologi kerusakan.

Evaluasi data hasil pemeriksaan dan pengujian.

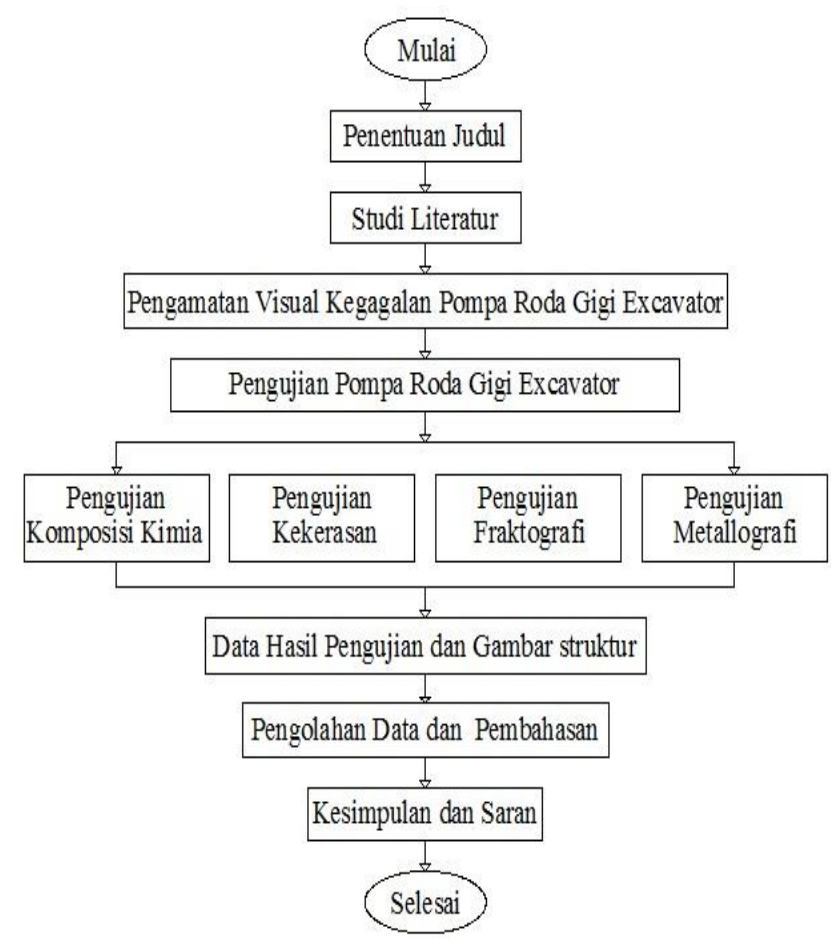

Gambar 1. Diagram alir penelitian 


\subsection{Pemeriksaan Visual}

Pemeriksaan ini diawali dengan pemeriksaan secara visual yaitu pemeriksaan secara langsung dari Gear Pump Excavator yang mengalami kerusakan, terutama pada permukaan Gear Pump Excavator yang aus. Pengamatan visual ini sangat penting dilakukan sebelum melangkah mendeteksi bentuk atau ciri kegagalan yang dialami oleh Gear Pump Excavator.

Pemeriksaan secara visual pada Gear Pump Excavator yang mengalami kerusakan meliputi :

$\checkmark$ Mencari awal aus/retak.

$\checkmark$ Pengambilan gambar foto dari berbagai arah.

$\checkmark$ Mengekspos posisi-posisi penting sebagai identifikasi informasi kerusakan.

\subsection{Pemeriksaan Fraktografi}

Pemeriksaan fraktografi digunakan untuk mengetahui adanya cacat material seperti adanya porosity, impurities, korosi, tingkat pertumbuhan retakan, menentukan lokasi dimulainya kerusakan/aus awal dan mengetahui jenis kerusakan karena adanya beban bentur, putar, tekan, geser, dan sebagainya.

Pengujian fraktografi dilakukan dengan menggunakan mikroskop stereo yang bermanfaat untuk mengetahui karakteristik permukaan patahan (surface fracture) pada bagian Gear Pump Excavator yang aus.

Pemeriksaan fraktografi dapat dilakukan pada dua skala pengamatan, yaitu makroskopik dan mikroskopik. Pemeriksaan makro fotografi dengan menggunakan mikroskop optic. Sebelum dilakukan pengujian spesimen benda uji dibersihkan dari kotoran melalui pencelupan ke dalam gelas beaker yang bersisi ethanel ditempatkan pada alat ultrasonic cleaner, selanjutnya dikeringkan dengan alat pengering.

\subsection{Pemeriksaan Metalografi}

Metalografi adalah gambaran mikro pada permukaan logam yang sudah dipreparasi. Gambaran struktur mikro itu tidak akan terlihat tanpa dipreparasi. Metalografi merupakan pengujian dan pengamatan terhadap strukutur butir suatu logam. Dalam pengamatan secara metalografi dapat diperoleh gambaran struktur butiran suatu logam. Pengujian metalografi harus menggunakan bantuan dari mikroskop optik. Metalografi merupakan disiplin ilmu yang mempelajari karakteristik mikrostruktur suatu logam dan paduannya serta hubungannya dengan sifat-sifat logam dan paduannya tersebut. Permukaan sampel harus benar-benar diratakan agar sampel yang telah dipreparasi dapat terlihat dan tergambar bentuk struktur mikro dari mikroskop sehingga cahaya yang berasal dari mikroskop akan mantul ke mata kita. Oleh karena itu, sebelum dilakukan pengamatan mikrostruktur dengan mikroskop maka diperlukan proses-proses persiapan sampel.

Pengujian metalografi bertujuan untuk mengamati struktur mikro dari bagian roda gigi yang aus, kemudian dibandingkan dengan material yang tidak mengalami kegagalan. Apakah ada perubahan struktur mikro yang terjadi pada material yang mengalami kerusakan. Alat yang digunakan adalah mikroskop optik metalurgi.

Tahapan dalam melakukan pengujian metalografi adalah sebagai berikut :
a. Pemotongan (cutting);
b. Pembingkaian (mounting);
c. Pangampelasan (grinding);
d. Pemolesan (polishing);
e. Pengetsaan (etching);
f. Pemotretan;

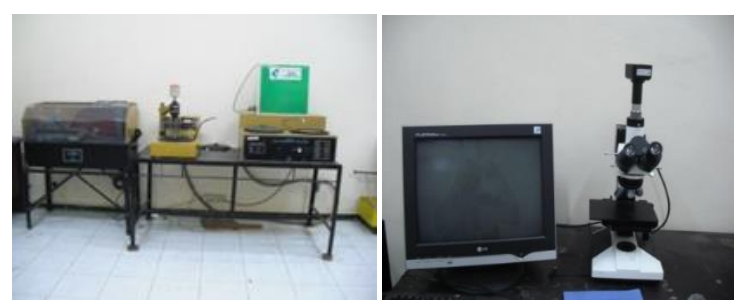

Gambar 2. Mesin Uji Metallografi

\subsection{Pengujian Kekerasan}

Material uji yang telah di metalogarafi selanjutnya digunakan untuk pengujian kekerasan, pada saat diuji material uji di polis kembali setelah itu di etsa menggunakan etsa NHO3 ( Asam Nitrat ) 2\%. Pengujian kekerasan menggunakan metode mikro hardness vikers, pengujian dilakukan di Laboratorium Puspitek Pengujian ini menggunakan alat uji mikro hardness vickers.

Pengujian kekerasan material Gear Pump Excavator dilakukan di Laboratorium Uji 
Konstruksi (LUK) /B2TKS BPPT dengan menggunakan metode kekerasan Vickers (hardness vickers) standar ASTM-A 743 CA6NM. Pengujian ini dilakukan untuk mengetahui kekerasan material Gear Pump Excavator dari daerah sekitar aus dan bagian lain yang tidak terpengaruh patahan/aus. Sebagai penetrator dipergunakan pyramid intan yang telah dikeraskan dan ditekan masuk ke dalam benda uji dengan beban dan waktu tertentu.

Prosedur dari pengujian kekerasan ini dapat dilihat pada diagram alir yang ditunjukkan pada gambar :

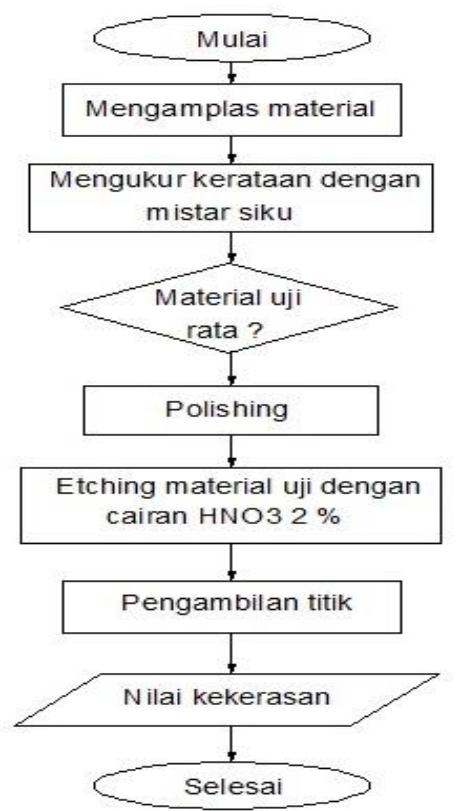

Gambar 3. Diagram alir pengujian kekerasan

Keterangan:

1. Pengamplasan material uji

2. Pengukuran kerataan

3. Polishing material uji

4. Etsa (Etching)

5. Pengambilan titik

Hasil pemeriksaan pengujian kekerasan Vickers pada dasarnya hampir sama dengan Brinells hanya identornya saja yang berbeda. Beberapa hal yang perlu diperhatikan pada metode pengujian kekerasan Vickers adalah sebagai berikut :

1. Spesimen harus memenuhi persyaratan: Permukaan harus rata dan Halus, Dapat ditumpu dengan baik dan permukaan horisontal
2. Identor yang digunakan adalah pyramid intan yang beralas bujur sangkar dengan sudut puncak antara dua sisi yang berhadapan adalah $136^{\circ}$.

3. Pada dasarnya semua beban bisa digunakan, kecuali untuk pelat yang tipis harus digunakan beban yang ringan.

4. Pada pelaksanaannya, pengujian kekerasan ini dilakukan dengan menekan identor pada permukaan specimen selama 10 - 30 detik.

Nilai kekerasan pengujian ini dinyatakan dalam satuan DPH (Vickers Diamond Pyramid Hardness) yang dihitung berdasarkan diagonal identasi dengan persamaan sebagai berikut :

$$
\mathrm{DPH}=\{2 \mathrm{P} \sin (\alpha / 2)\} / \mathrm{d}^{2}
$$

Untuk : $\alpha=136^{\circ}$

Dimana :

$$
\begin{aligned}
& \mathrm{P}=\text { Gaya tekan }(\mathrm{kgf}) \\
& \mathrm{d}=\text { diagonal identasi }(\mathrm{mm})
\end{aligned}
$$

Persamaan ini didapatkan dari Hasil tapak tekan pengujian vickers yang ditunjukkan pada gambar 4:

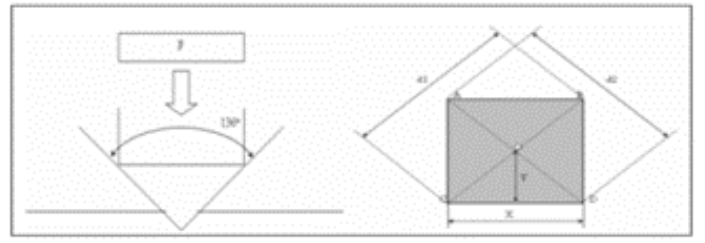

Gambar 4. Hasil Tapak Tekan Pengujian Vickers

$$
\begin{aligned}
& \mathrm{d}=\frac{\mathrm{d} 1+\mathrm{d} 2}{2} \\
& \mathrm{X}=\mathrm{d} \operatorname{Cos} 45^{\circ} \quad \mathrm{Y}=1 / 2 \mathrm{X} / \operatorname{Cos} 22^{\circ} \\
& \mathrm{L} \Delta \mathrm{AOB}=1 / 2 \mathrm{X} . \mathrm{Y} \\
& =\left(1 / 8 \mathrm{~d}^{2}\right) / \operatorname{Cos} 22^{\circ}
\end{aligned}
$$

$$
\begin{aligned}
\begin{aligned}
\mathrm{A} & =4 \mathrm{~L} \Delta \mathrm{AOB} \\
& =4\left(1 / 8 \mathrm{~d}^{2}\right) / \operatorname{Cos} 22^{0} \\
& =\left(1 / 2 \mathrm{~d}^{2}\right) / \operatorname{Cos} 22^{\circ}
\end{aligned} \\
\mathrm{HVN}=\mathrm{P} / \mathrm{A}=1,854 \mathrm{P} / \mathrm{d}^{2}
\end{aligned}
$$

5. Penulisan nilai kekerasan seperti contoh berikut : 150 DPH 150/10 
Dimana :

150 = Nilai Kekerasan

DPH $=$ Metode Pengujian Vickers

$150=$ Gaya Pembebanan (kgf)

10 = Waktu Pembebanan(detik)

6. Sama dengan pengujian kekerasan dengan brinells, karena pengukuran dilakukan secara manual maka terdapat kemungkinan terjadinya kesalahan ukur. Kesalahan itu mungkin terjadi pada saat pemfokusan objek pada layar, peletakan alat ukur pada objek dan pembacaan pengukurannya.

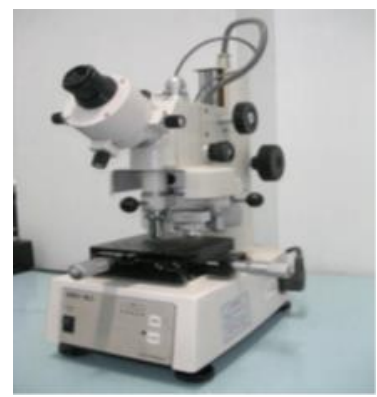

Gambar 5. Mesin Uji Mikro Hardness Vickers

\subsection{Pengujian Komposisi Kimia}

Analisis komposisi kimia Gear Pump Excavator, dilakukan di Laboratorium Balai Besar Teknologi Kekuatan Struktur (B2TKS) BPPT Puspitek Serpong. Pengujian analisis komposisi kimia pada material Gear Pump Excavator ini dilakukan dengan menggunakan spectrometer, untuk mengetahui jenis kandungan unsur kimia dan prosentasenya material Gear Pump Excavator yang mengalami kerusakan/ aus. Pengujian ini untuk mengetahui unsur utama material seperti kandungan: $\mathrm{C}, \mathrm{Mn}, \mathrm{P}, \mathrm{S}, \mathrm{Si}, \mathrm{Cr}$, $\mathrm{Ni}$.



Gambar 6. Mesin Uji komposisi kimia Spectrometer

\subsection{Vernier Caliper}

Jangka sorong ialah alat ukur yang ketelitiannya hingga seperseratus milimeter.

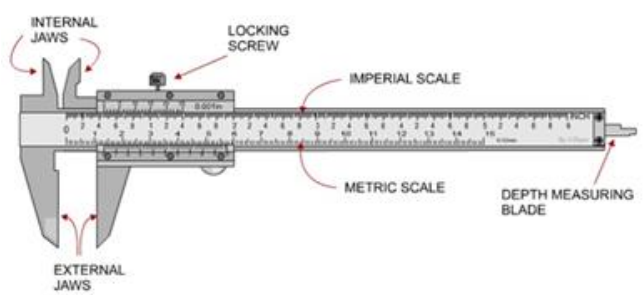

Gambar 7. Digital Ruler Vernier caliper

\subsection{Tempat dan Waktu Penelitian}

Penelitian ini dilaksanakan di laboratorium Pengujian Bahan B2TKS-BPPT Serpong dari bulan februari 2016 sampai April 2016 dimana jadwal pelaksanaannya dapat dilihat pada tabel 1 berikut.

Tabel 1.

Jadwal pelaksanaan

\begin{tabular}{|c|l|c|c|c|c|c|c|}
\hline No & Kegiatan & Jan & Feb & Mar & Apr & Mei & Jun \\
\hline 1 & $\begin{array}{l}\text { Penyusunan } \\
\text { proposal }\end{array}$ & $\vee \vee$ & & & & & \\
\hline 2 & $\begin{array}{l}\text { Pelaksanaan } \\
\text { penelitian }\end{array}$ & & $\vee \vee$ & $\vee \vee$ & & & \\
\hline 3 & $\begin{array}{l}\text { Pengolahan } \\
\text { data }\end{array}$ & & & & $\vee \vee$ & & \\
\hline 4 & $\begin{array}{l}\text { Penyusunan } \\
\text { laporan }\end{array}$ & & & & & $\vee \vee$ & $\vee \vee$ \\
\hline
\end{tabular}

\section{Hasil dan Pembahasan}

\subsection{Pengujian Fraktografi}

Hasil pemeriksaan Fraktografi menunjukan bahwa Gear Pump Excavator mengalami kerusakan pada gigi penggerak di bagian luar dan gigi bagian dalam. Photo makro roda gigi bagian luar dalam penampang melintang. Menunjukan adanya cacat Deformasi / Perubahan Bentuk akibat beban bentur pada permukaan roda gigi. Roda gigi yang menerima beban putar / gesek mengalami aus (lokasi 2) sesuai dengan arah putaran gear. Pada bagian permukaan roda gigi mengalami pengerasan permukaan. Fraktografi (mengacu pada ASTM E 340).

Dimana roda gigi ini memiliki diameter luar $145 \mathrm{~mm}$ dan diameter dalam $47 \mathrm{~mm}$ dan mempunyai lebar $30,5 \mathrm{~mm}$ adapun jumlah gigi bagian luar 34 buah dan gigi bagian dalam berjumlah 18 buah gigi. Dimana roda gigi ini jenis roda gigi miring ( Gambar 8 ). 


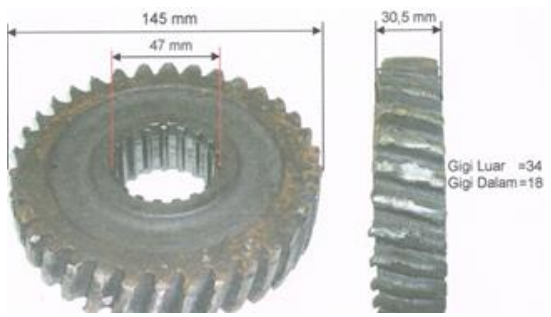

Gambar 8. Photo Penampang Gear Pump Excavator

Pada gambar 9 memperlihatkan bagian permukaan roda gigi terlihat bagian luar yang ada tanda panah merah terlihat kegagalan roda gigi (patahan) yang begitu hebat yang diakibatkan beban fatik (beban putar yang secara terus menerus).

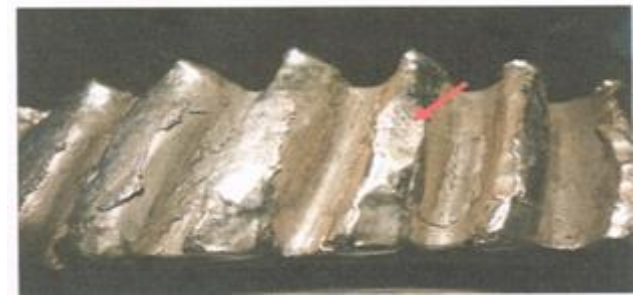

Gambar 9. Photo penampang bagian luar Gear Pump Excavator yang mengalami aus

Dari gambar dibawah (gbr 10) terlihat arah putaran roda gigi dimana roda gigi ini akan bergerak bila hidrolik nya bekerja. Tenaga hidrolik yang di hasilkan tergantung dari putaran roda gigi ini makin kencang putaran roda gigi ini maka cairan hidrolik yang di hasilkan cukup besar sehingga power yang di hasilkan juga meninggkat sehingga tekanan cairan hidrolik ini bertekanan tinggi.

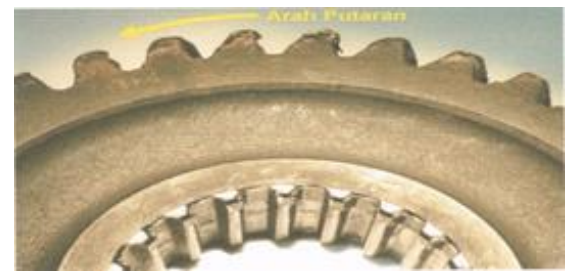

Gambar 10. Menunjukan arah putaran Gear Pump Excavator bagian luar

Kita perhatikan gambar 11 merupakan roda gigi bagian dalam dengan menunjukan arah putaran konstruksi roda gigi mempunyai prinsip kerja berdasarkan pasangan gerak. Bentuk gigi dibuat untuk menghilangkan keadaan slip, putar dan daya dapat berlangsung dengan baik.

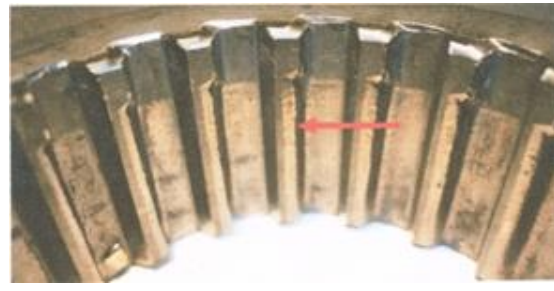

Gambar 11. Menunjukan arah putaran Gear Pump Excavator bagian dalam

Pada gambar 12 merupakan sampel roda gigi bagian dalam yang akan di lakukan pengujian, garis putus - putus merupakan daerah yang akan di lakukan pengujian.

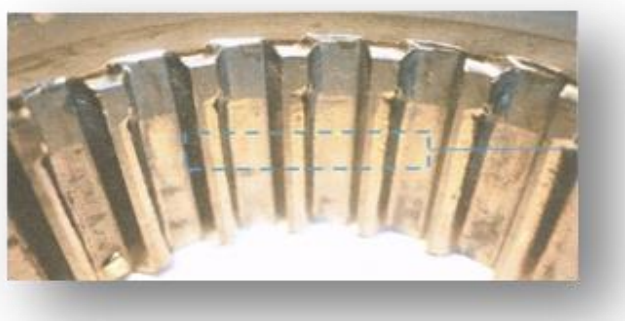

Gambar 12. Pengambilan sampel Gear Pump Excavator bagian dalam

Pada gambar 13 terlihat angka 1,2, dan 3 merupakan daerah gigi yang menerima beban sesuai dengan arah putaran. Pada permukaan gigi merupakan daerah yang permukaannya keras pada ujung gigi terlihat mengalami aus.

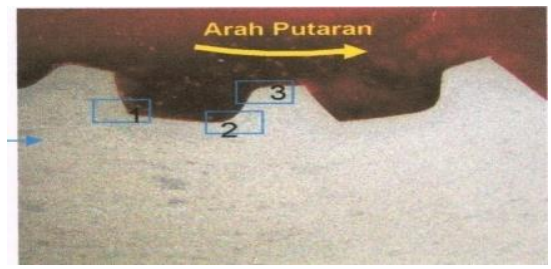

Gambar 13. Pengambilan sampel Gear Pump Excavator bagian dalam.

Pada gambar 14, terlihat kondisi roda gigi pada saat normal belum adanya beban (beban putar pada roda gigi tersebut) yang di berikan pada material tersebut sehingga nampak terlihat masih dalam kondisi bagus.

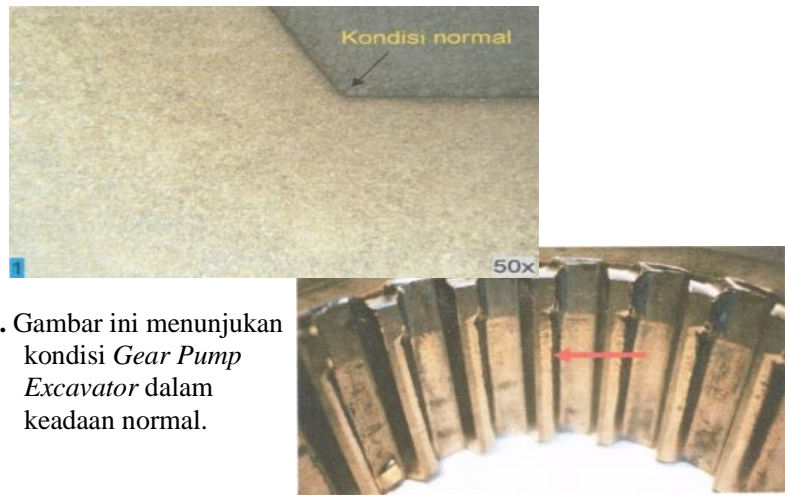


Roda gigi yang sudah di berikan beban secara berulang terus menerus akan mengalami aus karena roda gigi ini berpasangan sehingga dengan adanya beban yang secra terus menerus material tersebut mengalami kelelahan (fatiq) dan akan mengalami keausan akibat benturan dari kedua roda gigi tersebut (lihat gambar 15 di bawah)

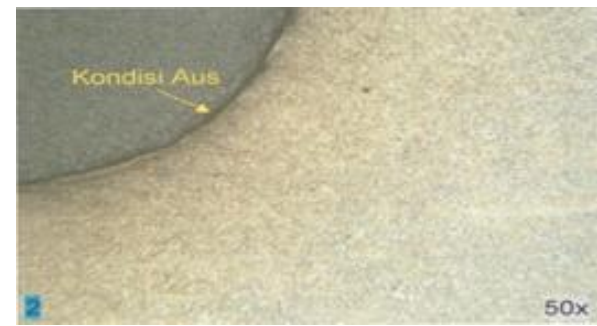

Gambar 15: Gambar ini menunjukan kondisi Gear Pump Excavator dalam keadaan aus.

Pada gambar 16 terlihat pada permukaan roda gigi mengalami deformasi gesek (perubahan bentuk ) akibat beban putar yang secara terus menerus. Gesekan fluida timbul apabila lapisan lapisan yang berdekatan dalam fluida (cairan atau gas ) bergerak pada kecepatan yang berbeda. Gerakan ini menimbulkan gaya gesekan antara elemen - elemen fluida, dan besar gaya ini tergantung pada kecepatan relatif antar lapisan. Apabila tidak ada kecepatan relatif seperti ini maka tidak ada gesekan fluida. Gesekan fluida bergantung tidak hanya pada gradien kecepatan dalam fluida, tetapi juga pada viskositas fluida yang merupakan ukuran hambatan terhadap aksi geseran antara lapisan - lapisan fluida.

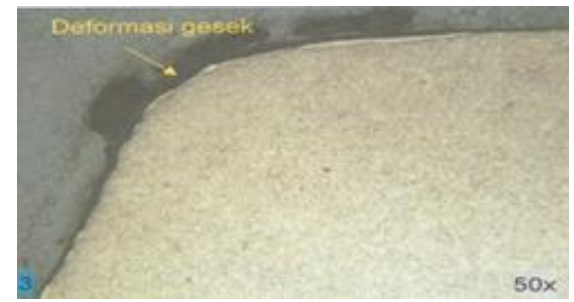

Gambar 16. Gear Pump Excavator mengalami deformasi gesek.

Dibawah merupakan daerah permukaan roda gigi sampel yang akan di uji (gambar 17) terlihat aus yang ada garis merahnya.

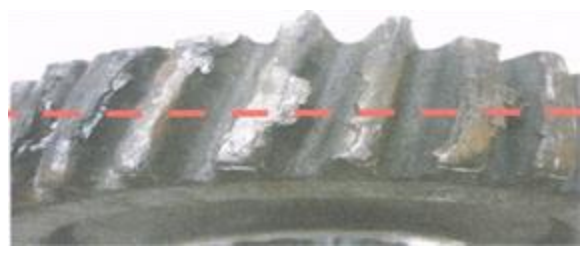

Gambar 17. Photo Sampel Gear Pump Excavator bagian luar
Dibawah ini merupakan sampel roda gigi yang akan di lakukan pengujian sebelum dilakukan pengujian benda tersebut di lakukan pengukuran dengan menggunakan jangka sorong dimana ukuran tersebut terlihat ukuran tinggi gigi $7 \mathrm{~mm}$.

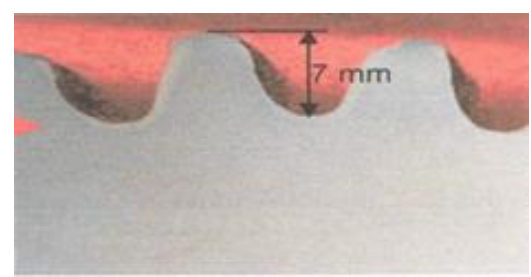

Gambar 18. Photo Sampel Gear Pump Excavator bagian luar ukuran tinggi gigi $7 \mathrm{~mm}$ )

Pada gambar 19 menunjukan daerah cacat deformasi pada titik 1, dan 2 dimana pada bagian ujung - ujung gigi terlihat patahan / aus nya roda gigi akibat beban bentur.

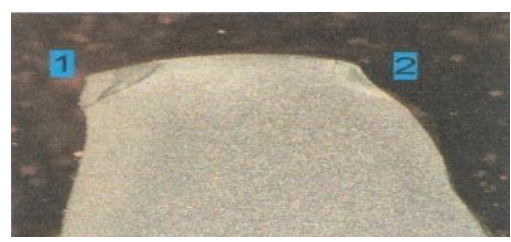

Gambar 19. Gambar permukaan bagian ujung gigi terlihat patah/ aus atau daerah cacat deformasi akibat beban bentur.

Permukaan gigi ujung pada gear pump excavator mengalami retak / patahan akibat bentur/ beban putar dapat dilihat pada gambar 14 dan 15 Lokasi 1 gambar ujung permukaan gigi yang di zoom terlihat retak / patahan akibat dari beban bentur terlihat cacat deformasi.

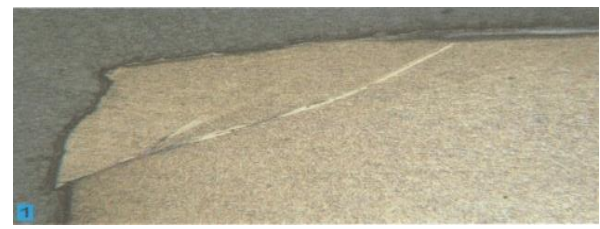

Gambar 20. Lokasi 1 gambar ujung permukaan gigi yang di zoom terlihat retak / patahan akibat dari beban bentur terlihat cacat deformasi

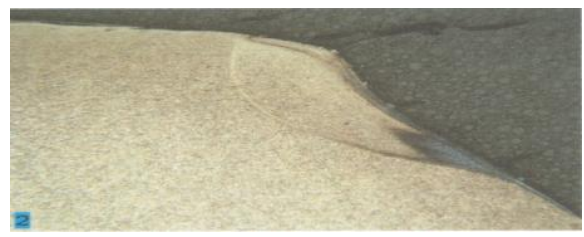

Gambar 21. Lokasi 2 gambar ujung permukaan gigi yang di zoom terlihat retak / patahan akibat dari beban bentur terlihat cacat deformasi

Ketika deformasi terjadi, gaya yang bekerja antar-molekul muncul melawan gaya yang diberikan. Jika gaya yang diberikan tidak terlalu 
besar maka kekuatan ini mungkin cukup untuk melawan gaya yang diberikan, yang memungkinkan objek untuk mencapai keadaan setimbang baru dan kembali ke kondisi semula ketika beban akan dihapus. Jika gaya yang lebih besar diberikan maka dapat menyebabkan cacat deformasi permanen dari objek atau bahkan menyebabkan kegagalan pompa roda gigi tersebut (Gambar 22 ).

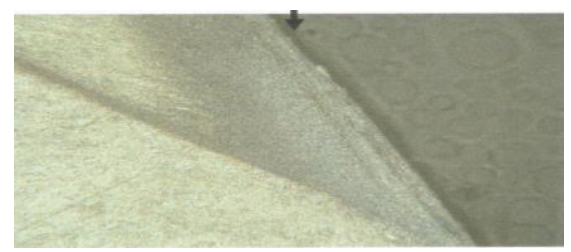

Gambar 22. Bagian Lokasi 2 yang lebih di zoom terlihat cacat deformasi akibat beban bentur.

\subsection{Pengujian Metalografi}

Hasil pemeriksaan Metalografi menunjukan bahwa struktur mikro lokasi 1, 2 \& 3 berupa martensit sedangkan di bagian tengah yang tidak mengalami pengerasan berupa Bainit Martensit. Dilihat dari bentuk kerusakan dan hasil dari pengamatan struktur mikro, tidak di temukan adanya retak atau cacat material lainnya, hanya terdapat deformasi mekanis akibat overload dalam pengoperasiannya. Metalografi (mengacu pada ASTM E 407).

Pada perbesaran 500X tampak halus jarumjarum plate martensite (hijau dan coklat), fasa austenit sisa (retained austenite) yang berwarna putih beserta bola-bola grafit (graphite) yang berwarna hitam (terlihat pada gambar yang di etsa menggunakan nital $2 \%$.

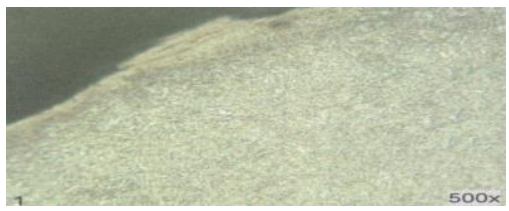

Gambar 23. Struktur mikro berupa martensit di zoom hingga 500x Etsa : nital 2\%

Martensit mengandung baja karbon rendah dengan logam campuran dan dengan cepat didinginkan dari suhu austenit, suatu unsur martensit terbentuk. Martensit tidak selalu ditemukan pada baja yang berkarbon rendah. Etsa khusus diperlukan untuk dapat membedakan martensit dari partikel cementite, pearlite dan austenit. Pada gambar ini struktur mikro dari martensit dinyatakan dengan warna gelap kecil (hitam) sedangkan yang tidak berwarna adalah austenit.
Butiran martensit tampak halus setelah di zoom hingga 500x berbentuk seperti lidi/jarum atau plat . Pada struktur martensit masih didapati struktur austenit yang tidak sempat bertransformasi.

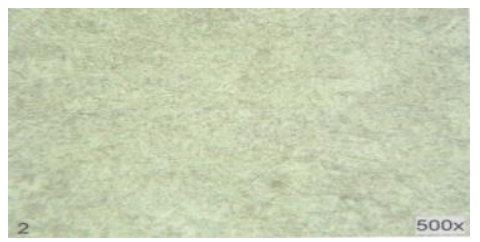

Gambar 24. Struktur mikro berupa martensit di zoom hingga 500x Etsa : nital 2\%

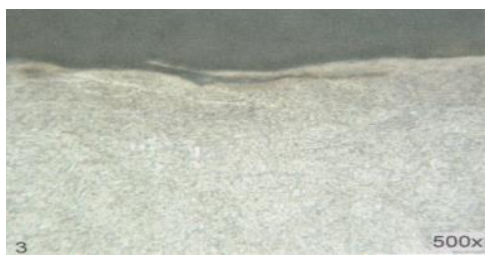

Gambar 25. Struktur mikro berupa martensit di zoom hingga 500x Etsa : nital 2\%

Fasa yang lain dari yang sudah disebutkan diatas adalah fasa martensit. Martensit terbentuk apabila besi austenit didinginkan dengan sangat cepat ke temperatur rendah, Martensit adalah fasa tunggal yang tidak seimbang yang terjadi karena transformasi tanpa difusi dari austenit. Pada transformasi membentuk martensit, lihat gambar 19 di bawah yang di zoom hingga 500x.

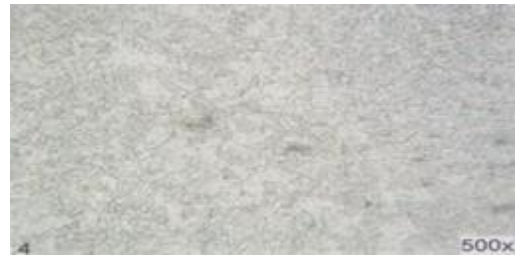

Gambar 26. Struktur mikro berupa martensit di zoom hingga 500x Etsa : nital 2\%

Gambar di bawah terlihat pada no. 123 dan 4 adalah daerah permukaan yang sangat keras dimana daerah permukaan gigi ini yang sering terjadi gesekan terhadap pasangan roda gigi dimana untuk memompakan cairan hidrolik, permukaan tersebut di zoom hingga $12 \mathrm{x}$ lihat gambar 27.

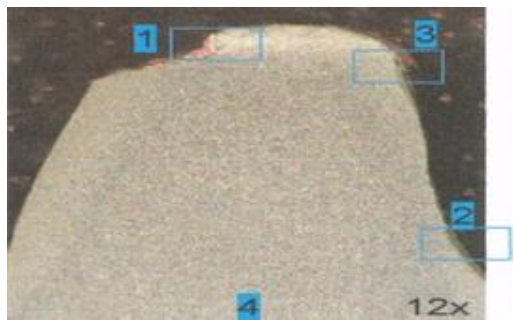

Gambar 27. Daerah titik 1, 2, 3, 4 merupakan daerah permukaan yang mengalami pengerasan 
Pada perbesaran 500X tampak lebih jelas titik titik martensite (coklat), fasa austenit sisa (retained austenite) yang berwarna putih beserta bola-bola grafit (graphite) yang berwarna hitam.

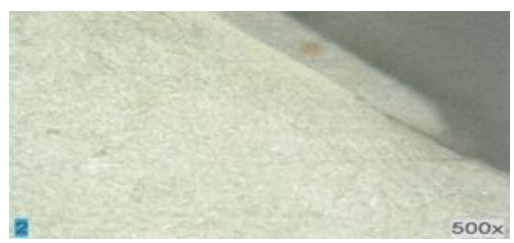

Gambar 28. Daerah titik 2 yang di besarkan (di zoom) hingga $500 \mathrm{x}$ berupa martensit yang mengalami deformasi berupa bainit-martensit

Martensit salah satu fasa yang dapat terbentuk pada struktur logam. Sifat dari sturktur pada fasa martensit adalah keras dan getas, jadi logam yang berada pada fasa ini cepat mengalami perpatahan atau deformasi. Untuk mendapatkan struktur dengan fasa martensit, maka logam haurs melalui proses perlakuan panas dengan laju pendinginan yang cepat. Untuk laju pendinginan yang cepat, biasanya digunakan air garam yang memiliki densitas yang sangat tinggi. Untuk lebih jelasnya, lihat gambar 29 fasa dari bahan yang memiliki struktur martensit. Gambar tersebut memperlihatkan struktur martensit yang mengalami deformasi.

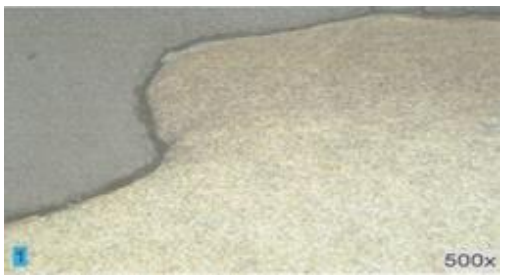

Gambar 29. Daerah titik 1 yang di besarkan (di zoom) hingga $500 \mathrm{x}$ berupa martensit yang mengalami deformasi

Kekerasan martensit sangat dipengaruhi oleh kadar karbon. Kekerasan martensit berkisar antara 20 - 65 HRC. Gambar dibawah memperlihatkan martensit yang mengalami deformasi yang di besarkan hingga 500x.

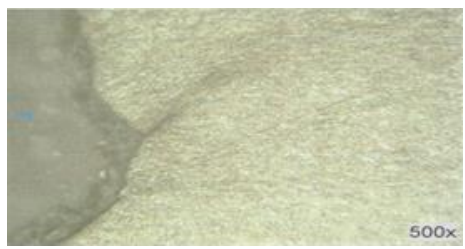

Gambar 30. Daerah titik 1 yang lebih di besarkan lagi (di zoom ) hingga $500 \mathrm{x}$ berupa martensit yang mengalami deformasi

Deformasi pada pompa roda gigi disebabkan oleh gaya atau perubahan temperatur di dalam material tersebut (pemuaian). deformasi, yang dideskripsikan sebagai perubahan relatif dari partikel-partikel pada material yang bukan merupakan benda kaku.

Dalam material kontinu, bidang yang terdeformasi dihasilkan dari tegangan yang diaplikasikan akibat adanya gaya atau pemuaian pada material.. Benda yang terdeformasi dapat kembali ke kondisi semula setelah gaya yang diaplikasikan dilepas, dan itu disebut sebagai deformasi elastis. Namun ada juga deformasi tidak dapat dikembalikan meski gaya telah dilepas, yang disebut dengan deformasi plastis, yang terjadi ketika benda telah melewati batas elastis atau yield dan merupakan hasil dari slip atau mekanisme dislokasi pada tingkat atom (Gambar 31).

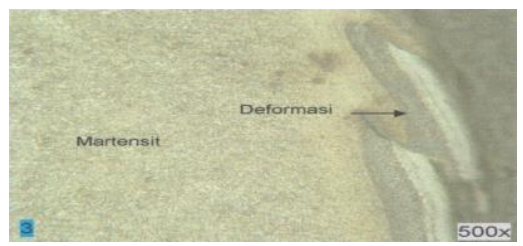

Gambar 31. Daerah titik 3 yang di besarkan (di zoom ) hingga $500 \mathrm{x}$ berupa martensit yang mengalami deformasi berupa martensit

Cacat inklusi terjadi karena masuknya terak atau bahan bukan logam ke dalam cairan logam akibat reaksi kimia selama peleburan, penuangan atau pembekuan.

Bainit menggambarkan struktur mikro pada baja yang di hasilkan dari dekomposisi austenit ke ferit dan sementit (Fe3C). Bainit terbentuk pada kisaran temperatur diatas transformasi martensit dan dibawah pembentukan perlit.

Setelah dipanaskan hingga suhu $800^{\circ} \mathrm{C}$, dan mencapai fasa austenit stabil, maka bahan didinginkan dengan cepat, yaitu dengan menggunakan media pendingin air garam. Digunakan air garam, karena memiliki densitas yang tinggi, dimana kerapatan antara molekul air garam amat tinggi, sehingga proses transfer panas berlangsung dengan waktu yang sangat cepat. Laju pendinginanpun berlangsung dengan cepat. Peristiwa ini mengakibatkan atom-atom karbon yang tadinya terlepas dari ikatan tidak mampu/sempat terredistrribusi ke dalam ikatan untuk mengikat atom-atom penyusun logam, dan atom-atom yang membesar tak sempat untuk mengecil. Jadi disini terjadi proses rekristalisasi yang sangat cepat. Dengan struktur yang seperti ini akan mengakibatkan ikatan yang tidak kuat antar satu atom dan atom lainnya sehingga sifatnya getas, dan keras, karena butiran yang membesar memenuhi ruang material. Sruktur semacam inilah yang disebut struktur martensit, yang terbentuk pada fasa martensit. Gambar 25. 
Jumlah inklusi sangat dipengaruhi oleh kandungan oksigen didalam material gear pump excavator (gambar 35).

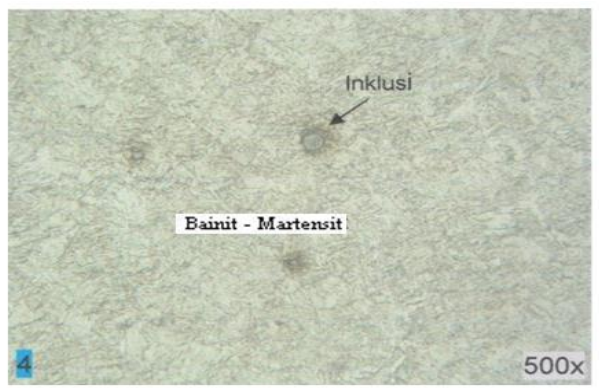

Gambar 32. Daerah titik 4 yang di besarkan (di zoom ) hingga $500 \mathrm{x}$ berupa martensit yang mengalami deformasi berupa bainit- martensit dan terlihat inklusi

\subsection{Pengujian Kekerasan Vicker}

\section{DIAGRAM ALIR UJ KEKERASAN VICKERS}

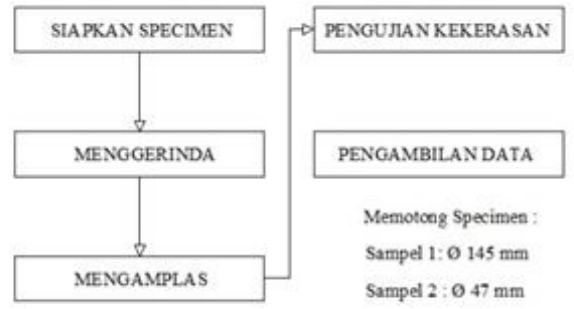

Gambar 33. Diagram alir uji kekerasan vickers

Uji kekerasan vickers menggunakan indentor piramida intan yang pada berbentuk bujur sangkar. Besar sudut antar permukaan piramida intan yang saling berhadapan adalah $136^{\circ}$.

Angka kekerasan vickers didefinisikan sebagai beban dibagi luas permukaan lekukan. Pengujian vickers ini mengacu pada standar ASTM E 384 - Rentang micro $(10 \mathrm{~g}-1000 \mathrm{~g})$, ASTM E 92 - Rentang macro (1kg - 100k), ISO 6507 - Rentang micro dan macro. Gambar dibawah (gambar 26) merupakan sampel untuk di lakukan pengujian kekerasan vicker.

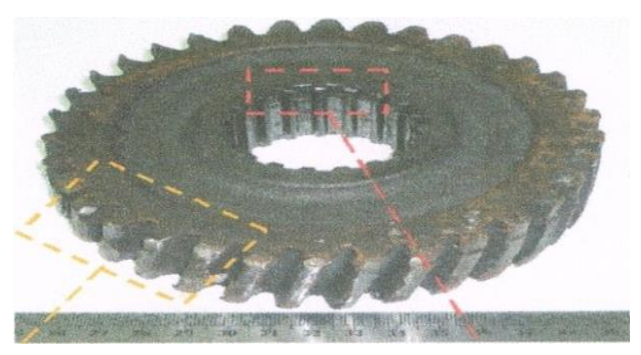

Gambar 34. Sampel Gear pump Excavator untuk dilakukan uji vickers.

Gambar 35 material pompa roda gigi untuk di lakukan pengujian vicker di ambil sampel 1 yaitu ada yang di titik permukaan gigi yaitu di titik 1 titik 2 titik 3 titik 4, ada juga yang agak jauh dari permukaan gigi yaitu di titik 5. Dimana hasil pengujian kekerasan pada titik 1 adalah 493 , selanjutnya bisa di lihat pada tabel 1 hasil pengujic



Gambar 35. Daerah sampel gambar roda gigi bagian luar yang di potong dari gambar 37 , adalah 5 titik daerah pengujian

$$
\text { kekerasan vikers }
$$

Pada gambar 39 yaitu sampel pompa roda gigi yang kedua dimana pengujian kekerasan vicker di lakukan pada permukaan gigi yaitu di titik 1 titik 2 titik 3 titik 4 sedangkan pada titik 5 letak nya lebih jauh dari permukaan gigi.



Gambar 36. Daerah sampel 2 gambar roda gigi bagian dalam yang di potong dari gambar 37 ,adalah 5 titik daerah pengujian kekerasan vikers.

Pengujian kekerasan dengan metode Vickers bertujuan menentukan kekerasan suatu material dalam yaitu daya tahan material terhadap indentor intan yang cukup kecil dan mempunyai bentuk geometri berbentuk piramid di bawah ini hasil uji kekerasan pada Gear Pump Excavator dapat dilihat pada tabel 2 hasil uji kekerasan

Tabel 2.

Hasil Uji Kekerasan Vickers Gear Pump Excavator

\begin{tabular}{ccc}
\hline \multirow{2}{*}{ No } & \multicolumn{2}{c}{ Nilai Kekerasan Vickers $(\mathrm{HV}) \mathrm{P}, 5 \mathrm{kgf}$} \\
\cline { 2 - 3 } & Sampel I & Sampel II \\
\hline 1 & 493 & 653 \\
2 & 396 & 376 \\
3 & 541 & 612 \\
4 & 537 & 441 \\
5 & 345 & 345 \\
\hline
\end{tabular}

4.4 Pengujian Komposisi Kimia 
Pengujian komposisi kimia adalah suatu pengujian yang bertujuan untuk mengetahui suatu jenis dan kandungan unsur kimia yang terdapat pada benda uji.

Alat yang digunakan dalam pengujian koposisi kimia ialah Spectrometer Analyzer Standar uji yang digunakan dalam pengujian komposisi kimia, tergantung jenis bahan dan alat yang digunakan untuk steel digunakan mengacu pada standar ASTM A 751.

Hasil Analisa Komposisi kimia menggunakan Spectrometer Analyzer dapat di lihat pada tabel 3 komposisi kimia.

Tabel. 3

Hasil Uji komposisi kimia Gear Pump Excavator

\begin{tabular}{|l|l|l|}
\hline \multirow{2}{*}{ Unsur } & \multicolumn{2}{|c|}{$\begin{array}{c}\text { Nilai Kandungan Unsur } \\
\text { (\%) }\end{array}$} \\
\cline { 2 - 3 } & \multicolumn{1}{|c|}{ Gear Pump Excavator } \\
\hline $\mathrm{Fe}$ & 97,1 & \multicolumn{1}{c|}{ Gigi } \\
$\mathrm{C}$ & 0,219 & 97,1 \\
$\mathrm{Si}$ & 0,362 & 0,225 \\
$\mathrm{Mn}$ & 0,764 & 0,334 \\
$\mathrm{Cr}$ & 1,14 & 0,777 \\
$\mathrm{Ni}$ & 0,0597 & 1,16 \\
$\mathrm{Mo}$ & 0,149 & 0,0535 \\
$\mathrm{Cu}$ & 0,103 & 0,151 \\
$\mathrm{Al}$ & 0,0276 & 0,0915 \\
$\mathrm{~V}$ & 0,0109 & 0,0265 \\
$\mathrm{~W}$ & 0,0250 & 0,0093 \\
$\mathrm{Ti}($ titanium) & 0,0021 & 0,0250 \\
$\mathrm{Nb}$ (Niobium) & 0,0213 & 0,0010 \\
$\mathrm{~B}$ (boron) & 0,0010 & 0,0073 \\
$\mathrm{~S}$ (belerang) & 0,0132 & 0,0147 \\
$\mathrm{P}$ (pospor) & 0,0218 & 0,0178 \\
\hline
\end{tabular}

\subsection{Penanggulangan dan Usaha Memperpanjang Umur Gear Pump Excavator}

Untuk memperpanjang umur pakai gear pump excavator akibat terjadinya beban putar/bentur dapat dilakukan dengan cara sebagai berikut :

1. Beban yang di gunakan setiap kali pengoperasian gear pump excavator tidak melebihi kapasitas (overlod)

2. Proses Perlakuan panas dengan Hardening dan tempering, untuk mendapatkan sifat tahan aus yang tinggi, kekuatan dan fatigue limit serta strength yang lebih baik.

3. Melakukan pelapisan permukaan dengan coating boron carbida, untuk mendapatkan lapisan permukaan yang lebih tahan aus dan rendah gesekan.

\subsection{Analisis dan Pembahasan}

Dari prosedur penelitian yang dilakukan di atas, pada pemeriksaan visual terlihat bahwa awal retak bermula dari daerah permukaan gear pump excavator, hal ini ditunjukkan oleh pemeriksaan makro dan dengan menggunakan mikroskop stereo. Perambatan retak yang berawal pada bagian permukaan juga tampak dari hasil pemeriksaan dengan mikroskop stereo. Pada gambar 1 terlihat gear pump excavator mengalami keausan. Gear pump excavator ini bekerja memutar menggerakkan roda gigi yang lain nya satu sama lain berkaitan sehingga dengan bekerjanya roda gigi secara terus menerus mengakibatkan adanya aus sehingga dengan adanya gaya putar/ bentur yang terus menerus maka gear pump excavator tersebut akan menimbulkan fatiq sehingga material akan mengalami deformasi atau perubahan bentuk akibat beban yang berulang.

Dari hasil Pengujian visual, Pengujian metalografi, Pengujian kekerasan dan Pengujian komposisi kimia material gear pump excavator, dapat dirumuskan hal sebagai berikut :

Penyebab utama terjadinya aus pada gear pump excavator adalah karena adanya beban fatiq atau beban putar pada permukaan gigi yang menyebabkan ketebalan gear pump excavator berkurang atau menipis yang sangat signifikan pada satu titik sehingga dengan adanya beban fatiq menyebabkan material tersebut terjadinya konsentrasi tegangan yang cukup besar serta menimbulkan panas yang berlebih sehingga material mengalami deformasi.

Dari hasil pengujian komposisi kimia pada plat logam $1 \mathrm{~mm}$ yang di uji dapat diketahui adanya 16 unsur dengan unsur yang paling dominan berupa ferrum, besi $(\mathrm{Fe})=97,1 \%$. Sehingga dilihat dari klasifikasi jenis ferrum, material ini termasuk jenis ferrum murni, karena kandungan unsur $\mathrm{Fe}>97,1 \%$. Selain unsur ferrum ( 97,1\%) terdapat juga kandungan unsur paduan/pengotor lainnya seperti $\mathrm{Fe}, \mathrm{C}, \mathrm{Si}$, Mn, Cr, Ni, Mo, Cu, Al, V, W, Ti, Nb, B, S, dan P. Dimana untuk ferrum murni memiliki kandungan campuran unsur karbon dengan besi.

\section{Simpulan}

Berdasarkan analisa dan pembahasan data hasil pengujian terhadap gear pump excavator tersebut maka dapat diambil beberapa kesimpulan :

1. Kegagalan sistem yang terjadi pada gear pump excavator yaitu adanya cacat Deformasi / Perubahan Bentuk akibat beban bentur pada permukaan roda gigi. 
Roda gigi yang menerima beban putar / gesek mengalami aus sesuai dengan arah putaran gear. Pada bagian permukaan roda gigi mengalami pengerasan permukaan.

2. Dilakukannya beberapa pengujian diantaranya pengujian Metalografi, Fraktografi, komposisi kimia dan pengujian kekerasan vickers. Selanjutnya hasil pemeriksaan Metalografi menunjukan bahwa struktur mikro lokasi berupa martensit sedangkan di bagian tengah yang tidak mengalami pengerasan berupa Bainit - Martensit.

3. Adanya distribusi inklusi yang berkonsentrasi di permukaan material gear pump excavatormenyebabkan konsentrasi tegangan (stress raiser).

Saran

1. Lakukan perawatan preventif sesuai buku petunjuk..

2. Melakukan pelapisan permukaan dengan coating boron carbida, untuk mendapatkan lapisan permukaan yang lebih tahan aus dan rendah gesekan dan juga tahan terhadap korosi erosi. Pelapisan permukaan dapat dilakukan dengan coating boron carbide setebal $0.5 \mu \mathrm{m}$ untuk mendapatkan kekerasan permukaan yang tinggi (mendekati kekerasan intan antara 4700 sampai 5000 pada skala knoop), daya tahan aus yang tinggi dan koefisien gesek rendah. Lapisan boron carbide memiliki daya tahan retak karena memiliki lapisan yang sangat halus dan tidak punya batas butir serta dapat digunakan pada temperatur relatif rendah < $2500 \mathrm{~F}(1210 \mathrm{C})$, Lapisan boron carbode dapat diproduksi dengan metoda : deposisi uap kimia dengan bantuan klorida dan teknik fluoride, konversi gas, percikan plasma dan reaksi sintering.

3. Perlu dilakukan Visual Inspection terhadap gear pump excavator yang lain untuk memastikan tidak ada cacat (defect)

\section{Daftar Pustaka}

[1] Abdullah Shahab, Dr.Ir.msc, "Analisa Kegagalan Suatu Komponen," staff pengajar jurusan teknik mesin, FTI-ITS.

[2] Amiril, Ir ; "Transmisi Roda Gigi”, ITN, Malang.

[3] Collins, J.A ; "Failure Of Material In Mechanical," Analysis, Prediction, dan Preventio, John Willey and Sons Inc, Canada, 1981.

[4] Popov , “Mechanics Of Materials," 2nd Edition, Versi SI, 1983.

[5] Harsokoesoemo, Dr., Ir., H. Darmawan ; "Kriteria Patah Lelah Untuk Perancangan Elemen Mesin," Jurusan Teknik Mesin, ITB , 1989

[6] "Kursus Singkat Aplikasi Praktis Mekanika Retakan", Laboratorium Aerodinamika Pusat Antas Universitas Ilmu Rekayasa, ITB, 1989.

[7] Metal Hand Book, 8 th Edition, Vol.7, "Atlas Of Microstructure Of Industrials Alloys."

[8] Colangelo dan F.A. Heiser,"Analysis Of Metallurgical Failure," 2nd Edition, 1987.

[9] B.J.M. Beumer Ing, 1980, "Pengetahuan Bahan Jilid II”I, Bhratara Karya aksara, Jakarta.

[10] Material Hand Book Vol 9, "Metallography Structure and Phase diagrams", ASM. 